\title{
Studi KeSesuaian Penerapan Standar Lingkungan Perumahan SEDERHana SeHat Di Kota Serang
}

\author{
Ria Nurul Fitri, Soedwiwahjono, Rufia Andisetyana Putri \\ Program Studi Perencanaan Wilayah dan Kota, \\ Jurusan Arsitektur, Fakultas Teknik \\ Universitas Sebelas Maret, Surakarta \\ email: rianurulfitri@gmail.com
}

\begin{abstract}
Serang city is the Capital City of Banten Province. As the time goes by, the population increases and the poor people needs an access to have a home. There are two housing environments, which is called "simple healthy housing environment" to help the poor people, which are Banten Indah Permai and Bumi Serang Timur, but the condition is the housing environments are lack of infrastructures and facilities. This problem makes a question how the suitability of simple healthy housing environment in Kota Serang is. The suitability study of simple healthy housing environment in Serang city is done by using scoring method analysis to count the suitability of the simple healthy housing environment standards as the output and perception of the people inside the housing environment as the outcome of this simple healthy housing environment. Descriptive comparative analysis is used also to know how output and outcome can match each other in the housing environment. Final scoring result obtained that Banten Indah Permai has been classified as suit in output because of the 58 score, but Bumi Serang Timur is not suit in output because it has 55 score. In outcome scoring, Banten Indah has been classified as suit in outcome for the 76,94 score, and also for Bumi Serang Timur has 75,68 for the outcome score. With comparative analyisis, this study also obtained that there are many infrastructure and facilities in housing environment which are not give the outcome as usual the housing environment gives.
\end{abstract}

Keywords: simple healthy housing, suitability, scoring, environment,

\section{PENDAHULUAN}

Kota adalah tempat dengan konsentrasi penduduk lebih padat dari wilayah sekitarnya karena terjadi pemusatan kegiatan fungsional yang berkaitan dengan kegiatan penduduknya (Kustiwan, Nia 2009 : 5). Salah satu bidang di mana selalu ada kekurangan baik di negara maju maupun berkembang yang diakibatkan oleh tekanan jumlah penduduk ialah bidang perumahan dan permukiman (Soesilowati, 2007). Pelaksanaan pembangunan perumahan dan permukiman tentu tidak lepas dari berbagai kendala, yang antara lain terbatasnya lahan yang dibarengi dengan meningkatnya pembangunan serta perkembangan jumlah penduduk yang pesat, telah mengakibatkan adanya ketimpangan antara jumlah permintaan dengan penawaran.
Ketimpangan ini memacu meningkatnya nilai lahan yang digunakan untuk mengembangkan perumahan dan permukiman sehingga untuk mendapatkan lahan, terutama bagi masyarakat yang berpenghasilan rendah, menjadi semakin sulit (Sastra, Endy, 2006).

Semenjak pembentukan Kota Serang pada tanggal 2 November 2007, jumlah penduduk di Kota tersebut pun semakin meningkat menjadi $3,6 \%$ di tahun 2011 dan terus berlanjut sampai sekarang. Keberadaan penduduk miskin juga tidak dapat dihindari. Hal ini terlihat dengan persentase jumlah penduduk miskin sebesar $6,25 \%$ dari jumlah penduduk di Kota Serang, yaitu sebesar 3271 jiwa (BPS Kota Serang, 2011). Dalam memenuhi kebutuhan masyarakat tersebut akan perumahan tersebut, kota 
Serang pada tahun 2013 sudah membangun 2 lingkungan perumahan formal yang dibuat oleh developer swasta yang merupakan lingkungan perumahan sederhana sehat, yaitu lingkungan Perumahan Banten Indah Permai dan Bumi Serang Timur (APERSI, 2013).

Walaupun perumahan tersebut telah melalui proses perizinan di pemerintahan setempat akan tetapi beberapa lingkungan perumahan formal sederhana sehat tersebut dalam keadaan memprihatinkan. Perumahan Banten Indah Permai sejak dibangun pertama kali jalannya tidak pernah diperbaiki. Padahal jalan tersebut merupakan satu-satunya akses jalan masuk jalan yang jaraknya hanya sekitar 600 meter dari gerbang perumahan ke rumah warga kondisinya sangat memprihatinkan sehingga mengganggu aksesibilitas masyarakat (bantenposnews.com). Kota Serang pun belum memiliki sarana kesehatan posyandu yang representatif guna memenuhi kebutuhan penduduk (kabarpublik.com) dan juga sarana pendidikan yang tidak tersebar secara merata dan akses ke perumahan bagi golongan menengah ke bawah (Saraswati, 2011). Selain itu, lingkungan perumahan Bumi Serang Timur juga rawan akan terjadinya banjir (Dinas PU Kota Serang, 2013).

Dengan melihat permasalahan yang telah ada terkait lingkungan perumahan sederhana sehat di Kota Serang tentunya perlu diketahui apa dan bagaimana kesesuaian dalam penerapan standar lingkungan perumahan sederhana sehat di lingkungan Perumahan Banten Indah Permai dan Bumi Serang Timur sudah dapat meningkatkan kualitas penduduk di Kota Serang.

\section{METODE}

\subsection{Ruang Lingkup}

a. Ruang lingkup wilayah

Ruang lingkup wilayah yang menjadi target penelitian adalah seluruh lingkungan perumahan sederhana sehat di Kota Serang, Provinsi Banten, yaitu lingkungan perumahan Banten Indah Permai dan Bumi Serang Timur. b. Ruang Lingkup Populasi

Ruang lingkup populasi adalah seluruh lingkungan perumahan sederhana sehat di Kota Serang dan seluruh penghuni lingkungan perumahan sederhana sehat di Kota Serang.

c. Ruang lingkup substansi

Ruang lingkup dalam substansi penelitian ini adalah analisis kesesuaian penerapan standar lingkungan perumahan sederhana sehat di Kota Serang. Dalam hal ini akan dikaji kesesuaian penerapan standar lingkungan perumahan sederhana sehat sebagai luaran dan persepsi masyarakat terkait penerapan standar lingkungan perumahan sederhana sehat sebagai akibat yang nantinya akan dikomparasikan antara luaran dan akibat tersebut.

\subsection{Metode Analisis}

Dalam tahapan ini dilakukan tiga analisis, yakni sebagai berikut:

1. Analisis skoring kesesuaian penerapan standar lingkungan perumahan sederhana sehat yang digunakan untuk mengukur tingkat kesesuaian luaran.

2. Analisis skoring kesesuaian persepsi masyarakat terkait lingkungan perumahan sederhana sehat yang digunakan untuk mengukur tingkat kesesuaian akibat.

3. Analisis komparasi antara luaran dan akibat untuk mengukur kesinambungan antara luaran dan akibat.

\section{HASIL DAN PEMBAHASAN}

3.1 Analisis Kesesuaian Penerapan Standar Lingkungan Perumahan Sederhana Sehat

Analisis ini menggunakan metode skoring yang nantinya akan diketahui tingkat kesesuaian penerapan standar lingkungan perumahan sederhana sehat untuk mengukur luaran. Tingkat kesesuaian dikelompokkan menjadi tiga kelas, yaitu sangat sesuai, sesuai, dan tidak sesuai. Dari hasil perhitungan dapat 
diketahui bahwa lingkungan perumahan Banten Indah Permai memiliki nilai 58 dan masuk dalam kategori sesuai, sementara lingkungan Perumahan Bumi Serang Timur memiliki nilai 55 dan masuk dalam kategori tidak sesuai.

\subsection{Analisis Kesesuaian Persepsi Masyarakat terkait Penerapan Standar Lingkungan Perumahan Sederhana Sehat}

Sama seperti analisis sebelumnya, analisis ini menggunakan metode skoring yang nantinya akan diketahui tingkat kesesuaian persepsi masyarakat terkait penerapan standar lingkungan perumahan sederhana sehat untuk mengukur akibat. Tingkat kesesuaian dikelompokkan menjadi tiga kelas, yaitu sangat sesuai, sesuai, dan tidak sesuai. Dari hasil perhitungan dapat diketahui bahwa lingkungan perumahan Banten Indah Permai memiliki nilai 76,94 dan masuk dalam kategori sesuai. Serupa dengan lingkungan Perumahan Bumi Serang Timur, lingkungan perumahan ini masuk dalam kategori sesuai dengan nilai 75,98.

3.3 Analisis Komparasi Luaran dan Akibat

Analisis ini digunakan untuk mengkaji apakah luaran berupa penerapan standar lingkungan perumahan menghasilkan akibat yang sesuai berupa persepsi masyarakat lingkungan perumahan tersebut. Dari analisis yang telah dilakukan dapat diketahui bahwa dari segi prasarana dan utilitas lingkungan Perumahan Banten Indah Permai sudah memiliki kesinambungan akibat yang sesuai dari penerapan standar tersebut. Akan tetapi, terkait penerapan sarana dapat diketahui bahwa meskipun sarana di lingkungan perumahan tersebut memiliki jangkauan yang melebihi standar akan tetapi masyarakat tidak merasa bahwa sarana tersebut dapat mengganggu kegiatan masyarakat. Hal ini juga terjadi pada lingkungan Perumahan Bumi Serang Timur yang memiliki ketidaksesuaian di bidang sarana yang jangkauannya melebihi standar akan tetapi masyarakat pun tidak merasa terganggu dengan ketidaksesuaian penerapan standar tersebut.

\section{KESIMPULAN}

Dari penelitian yang telah dilakukan, dapat diketahui bahwa dari segi penerapan standar sebagai luaran, lingkungan Perumahan Banten Indah Permai masuk dalam kategori sesuai sementara lingkungan Perumahan Bumi Serang Timur masuk dalam kategori tidak sesuai.

Adapun dari segi penerapan standar sebagai akibat, lingkungan Perumahan Banten Indah Permai dan Bumi Serang Timur keduanya masuk dalam kategori sesuai dengan perbedaan skoring nilai yang tidak terlampau jauh meskipun secara penerapan standar lingkungan perumahan sederhana sehat keduanya memiliki karakteristik yang berbeda,

Walaupun dari segi tingkat kesesuaian penerapan standar lingkungan perumahan sederhana sehat lingkungan perumahan Bumi Serang Timur masuk dalam kategori tidak sesuai, akan tetapi setelah dilihat tingkat kesesuaian lingkungan perumahannya nyatanya kedua lingkungan perumahan sederhana sehat tersebut masuk dalam kategori sesuai.

Dalam komparasi antara luaran dan akibat dapat diketahui pula bahwa terdapat beberapa penerapan standar lingkungan yang tidak menghasilkan akibat yang buruk. Hal ini mengindikasikan bahwa standar-standar lingkungan perumahan sederhana sehat yang sebelumnya sudah ditetapkan tidak seluruhnya membuat akibat standar lingkungan tersebut menjadi tidak sesuai dengan yang diinginkan.

\section{REFERENSI}

APERSI. 2013. Daftar Perumahan Sederhana Sehat di Kota Serang. Serang : APERSI.

BPS Kota Serang. 2012 Serang dalam Angka. Serang : BPS Kota Serang. Diakses melalui

:http://serangkota.bps.go.id/publikasi/dda 2012/index.html

Dinas PU Kota Serang. 2013. Profil Sanitasi Kota Serang. Serang : Dinas PU Kota Serang.

http://bantenposnews.com/berita-4459pengembang-bip-abaikan- 
fasum.html\#.UmWxfoaVPio

(Diakses

tanggal 3 Desember 2013 jam 21.01)

http://www.kabarpublik.com/2012/03/posyan

du-di-kota-serang-belum-miliki-tempat/

(Diakses 6 Januari 2014 jam 19.00)

Kustiwan, Iwan, dan Nia K.Pontoh. 2009.

Pengantar Perencanaan Perkotaan.

Bandung : ITB Bandung.

Saraswati, Ratna. 2011. Kualitas Pendidikan

Dasar di Kota Serang Provinsi Banten.

Singaraja : Undiksha. Diakses melalui : http://pasca.undiksha.ac.id/media/673.pdf

Sastra, Suparno M., Endy Marlina. 2006.

Perencanaaan dan Pengembangan

Perumahan. Yogyakarta :Andi Publisher.

Soesilawati, Etty. 2007. Kebijakan

Perumahan Dan Permukiman Bagi

Masyarakat Urban. Semarang : Unnes.

Diakses

melalui

http://journal.unnes.ac.id/nju/index.php/jd

/article/view/1479/1604 